\title{
Ontario Medical Association position paper on health effects of ground-level ozone, acid aerosols and particulate matter
}

\author{
B Ted Boadway MD CCFP, Judith MacPhail MHSc, Carol Jacobson BPT MHSc \\ Ontario Medical Association, Toronto, Ontario
}

BT Boadway, J MacPhail, C Jacobson. Health effects of ground-level ozone, acid aerosols and particulate matter. Can Respir J 1998;5(5):367-384.

This review of the evidence of the health effects of air pollutants focuses on research conducted in Ontario. Seven key Ontario studies are cited. These findings are highly significant for people living in the Great Lakes basin (and particularly the Windsor-Quebec corridor), where high levels of certain air pollutants (eg, ground-level ozone and ultra-fine particles) occur more frequently than in other parts of Canada. The issue is a serious one, requiring an integrated and comprehensive approach by many stakeholders, including the active involvement of organized medicine. It is important that the health effects of these air pollutants are understood. Governments must act to reduce emission levels through statue and regulation bolstered by noncompliance penalties.

The findings of research have included the following: in a Toronto study, a $2 \%$ to $4 \%$ excess of respiratory deaths were attributable to pollutant levels; children living in rural Ontario communities with the highest levels of airborne acids were significantly more likely to report at least one episode of bronchitis, as well as to show decreases in lung function; and have been linked to increases in pollutants, emergency room visits and hospitalizations in Ontario.

Every Ontarian is affected by air pollutants, although he or she may be unaware of the asymptomatic effects such as lung and bronchial inflammation. This health problem is preventable; while physicians know of the adverse health impacts of air pollution and they are concerned, individually they now focus on the treatment of symptoms. The major recommendations of the report are as follows:
- Enactment of more stringent sulphur and nitrogen oxide emission limits, including a provincewide sulphur dioxide reduction of $75 \%$ from current cap levels, and the maximum allowable nitrogen oxides emission limits of 6000 tonnes annually from Ontario Hydro.

- New transportation sector emission limits that should include California-level standards for light and heavy duty vehicles, reductions from off-road engines, an expanded vehicle inspection and maintenance program, and tougher standards for sulphur-infuel content.

- Petitioning the United States Environmental Protection Agency administrator under Section 115 of the United States Clear Air Act to require reductions in the American emission of sulphur dioxide and nitrogen oxides, which damage the health of Canadian residents and their environment.

- Physician advice to patients about the risks of smog exposure, physician support for more health effects research on air pollution, and physician promotion of the development of air pollution-related health education materials.

The recommendations discussed in this paper will, if acted upon, lead to a significant reduction in the overall burden of illness from air pollutants, especially in children and the elderly. These recommendations have been selected from a review of recommendations made by various authorities, and are those that the OMA feels a particular responsibility to support.

Key Words: Epidemiology, Health effects/impacts, Health policy, Outdoor air pollution, Risk groups, Sensitive subgroups, Smog, Tropospheric ozone

Pour le résumé, voir page 368

This paper is an edited version of the original report, which is available on the Ontario Medical Association website www.oma.org

Correspondence and reprints: Dr Ted Boadway, Ontario Medical Association Health Policy Department, 525 University Avenue, Suite 300, Toronto, Ontario M5G 2K7. Telephone 416-340-2942, fax 416-340-2238, e-mail ted_boadway@oma.org 


\section{Prise de position de l'Association médicale de l'Ontario sur les effets de l'ozone au ras du sol, des aérosols acides et des particules sur la santé}

RÉSUMÉ : :Le présent article de revue sur les preuves des effets des polluants contenus dans l'air sur la santé se concentre sur la recherche menée en Ontario. Sept études ontariennes clés sont citées. Ces résultats sont fortement significatifs pour les personnes qui vivent dans le bassin des Grands Lacs (surtout le corridor WindsorQuébec), où des concentrations élevées de certains polluants atmosphériques (par exemple, l'ozone au ras du sol et des particules ultrafines) sont enregistrées plus souvent que dans d'autres régions du Canada. Il s'agit d'un problème inquiétant exigeant une approche globale et intégrée de la part de nombreux décideurs, y compris l'implication active des organismes médicaux. Il est important que les effets de ces polluants atmosphériques sur la santé soient compris. Les gouvernements doivent agir pour réduire les niveaux d'émission au moyen de lois et de règlements renforcés par des pénalités lorsque ces règlements ne sont pas observés.

Les résultats de cette recherche comprennent les éléments suivants : dans une étude torontoise, un excès de $2 \%$ à $4 \%$ des décès dus à une maladie respiratoire étaient attribuables aux concentrations des polluants ; les enfants qui vivent dans les communautés rurales de l'Ontario où les concentrations d'acides contenus dans l'air sont les plus élevées, étaient de façon significative plus à risque de rapporter au moins un épisode de bronchite et d'accuser une diminution de la fonction pulmonaire, et qui ont été reliées aux augmentations des polluants, aux visites à la salle des urgences et aux hospitalisations en Ontario.

Toute la population ontarienne est touchée par les polluants atmosphériques, même si elle n'est pas consciente des effets asymptomatiques tels que l'inflammation bronchique et pulmonaire. Ce problème de santé est évitable ; alors que les médecins connaissent les impacts indésirables de la pollution atmosphérique sur la santé, et qu'ils s'en inquiètent, sur une base individuelle, ils s'attachent actuellement à en traiter les symptômes. Les principales recommandations du rapport sont les suivantes :

- Promulgation de limites d'émission plus rigoureuses pour les oxydes de soufre et d'azote, comprenant une réduction du dioxyde de soufre à l'échelle de la province de $75 \%$ par rapport aux limites actuelles, et une émission maximale d'oxydes d'azote limitée à 6000 tonnes par an pour Hydro-Ontario.

- Définition de nouvelles limites d'émission pour le domaine des transports qui devraient inclure les normes d'émission californiennes pour les poids lourds et les véhicules légers, des réductions pour les véhicules tout terrain, et un élargissement du programme d'inspection et d'entretien des véhicules, et des normes plus strictes pour le contenu en soufre du carburant.

- Adresser une pétition à l'administrateur de la United States Environmental Protection Agency d'après la Section 115 du Clear Air Act des États-Unis pour exiger des réductions américaines de l'émission de dioxyde de soufre et des oxydes d'azote, qui endommagent la santé des canadiens et leur environnement.

- Conseils des médecins aux patients concernant les risques de l'exposition au smog, soutien des médecins en faveur d'une recherche plus intensive sur les effets de la pollution atmosphérique sur la santé, et promotion par les médecins du développement de matériel pédagogique ayant un rapport avec la pollution atmosphérique.

Les recommandations discutées dans cet article conduiront, si elles sont suivies, à une réduction significative du fardeau global de la maladie causée par les polluants atmosphériques, surtout chez les enfants et les personnes âgées. Ces recommandations ont été tirées d'un rapport sur les recommandations énoncées par différentes autorités, et représentent les recommandations que 1'Association médicale de l'Ontario croit devoir soutenir.
$\mathrm{O}$ tario's air quality has a mixed record. Over the past 24 years, improvement has been shown for a number of pollutants as a result of abatement programs designed to reduce emissions and enforcement of regulations by government (1). However, annual average ground-level ozone levels in the Great Lakes basin (southern Ontario and Windsor-Quebec corridor) have been consistently higher than the National Ambient Air Quality Objective of 15 parts per billion ( $\mathrm{ppb}$ ) for the past several years. In general, levels of particulates and sulphates in the basin have not declined (2). Provincial average nitrogen oxide concentrations remained relatively constant throughout the latter half of the 1980s, followed by a slight decrease in the 1990s (3). However, a principal concern is the restructuring of the electricity generation sector and a potential increase in the use of coal to generate low cost electricity. In Ontario, fossil fuel generating stations are major emitters of pollutants such as nitrogen oxides and particulate matter (4).

At current levels of exposure, pollutants such as ground-level ozone, inhalable particulates and total sulphur compounds are responsible for adverse health effects in Ontarians. There are concerns about whether the existing standards for environmental exposures provide adequate protection and about the potential risks of new and unevaluated agents (5).

For Ontarians living in a province known for its open spaces and fresh air activities, air quality is a very important concern (2). The West Central Region of the Ministry of
Environment, Ontario (MOE) alone logs about 500 air quality complaints annually, and the issue receives frequent media coverage (6).

Over the past decade, scientific research has uncovered health effects of air pollution that range from difficulty in breathing to coughing and wheezing, and aggravation of existing cardiac and respiratory conditions. These effects may result in visits to a doctor or an emergency room, an increase in medication use, admissions to hospital or even premature death. For sensitive individuals, any increase in air pollution, no matter how small, can cause underlying illnesses to become more severe. The severity and types of health effects associated with air pollution vary widely and are both acute and chronic. The research findings are highly significant for people living in the Great Lakes basin, where episodes of high levels of certain air pollutants (particularly ground-level ozone) occur more frequently than in other parts of Canada (Figure 1) (2).

The scope of physician involvement with air pollution is broad, ranging from issues arising in the care of the individual patient to population health concerns. Although individual physicians manage the burden of disease in the form of patient illness and death, the causes of health effects by air pollution should be addressed collectively by physicians.

The purpose of this paper is to outline the Ontario Medical Association's (OMA) position regarding the adverse health 


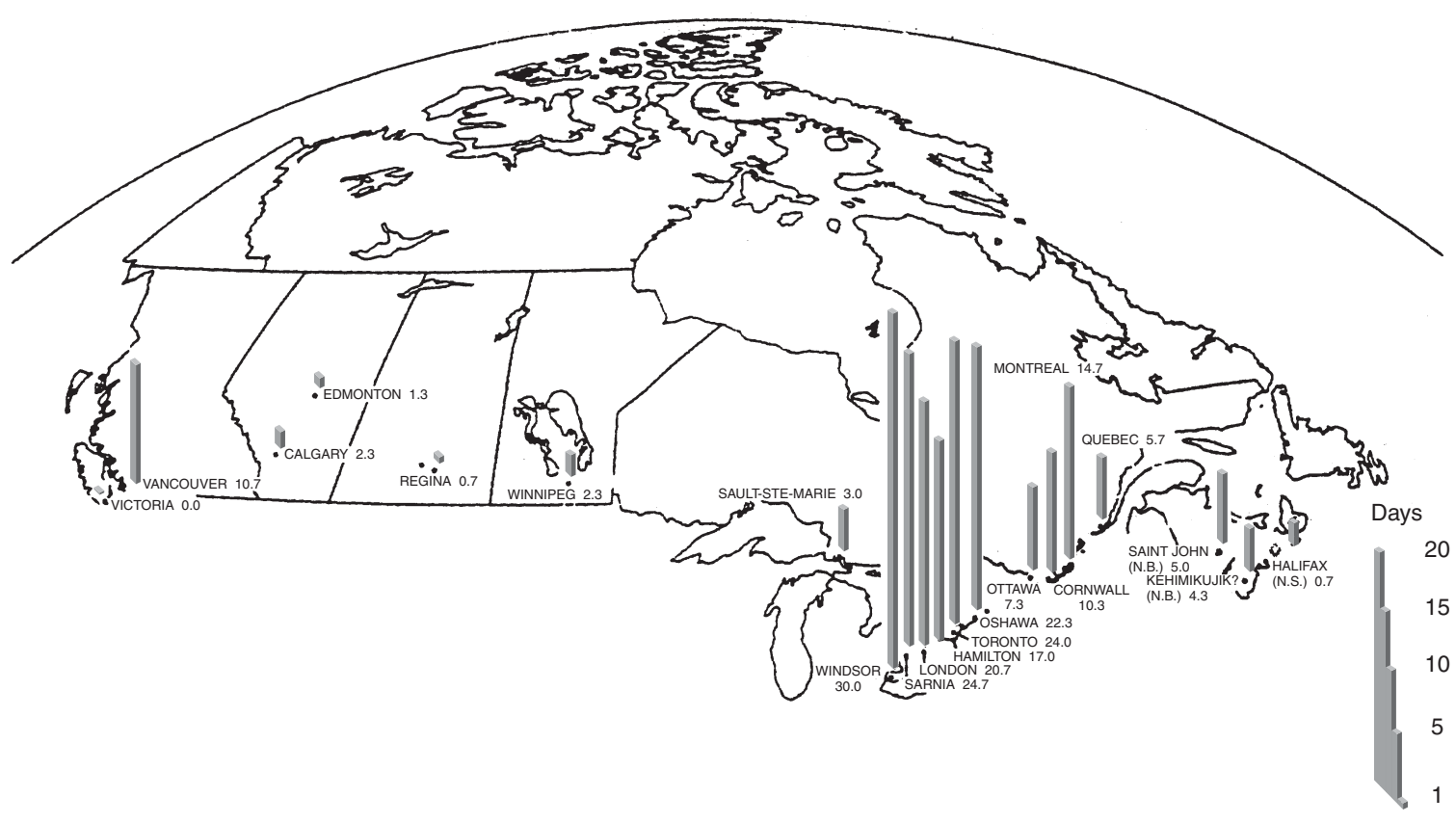

Figure 1) Number of days per year with ozone levels in excess of the 1 h air quality objective of 82 parts per billion, average of the three highest years (1983-1990). Source: Environment Canada, 1994

effects of ground-level ozone, particulate matter and acid aerosols. It provides an overview of the health effects of these pollutants from current research in the field, and recommends a set of key remedial strategies for the OMA, individual physicians and the public.

\section{BACKGROUND}

During the 1970s, much rethinking of the concepts of health, the environment and their relationship took place. The Lalonde Report (7) was a landmark document that recognized that health has multiple determinants - including human biology (genetic and physiological characteristics such as changes in the human body due to maturation and aging), the environment (both social and physical dimensions) and lifestyle (such as the proportion of the population who use tobacco products). 'Determinants' are factors that are not health problems per se, but are believed to be related to the development of disease. Air quality is a key environmental determinant of health (8).

The Ontario MOE (1) gathers air quality data at many locations in the province. These data assess the state of air quality in Ontario and help develop abatement programs to reduce the burden of air pollutants. The ongoing downsizing of the MOE, undertaken to achieve cost savings, makes it unlikely that additional efforts will be made to advance protection and improvement of air quality. There were $40 \%$ fewer provincial staff in 1997 than in 1990 to monitor air quality, handle spills and set standards, etc. Provincial plans to address air quality standards by 1999 include only one-third of 226 chemicals identified in the Ministry's own 1992 review (9).

\section{AIR POLLUTANTS}

Sources and distribution: $\mathrm{Smog}$ is the term given to the chemical 'soup' that is produced by photochemical reactions among nitrogen oxides and volatile organic compounds. The main components of smog in eastern North America are elevated concentrations of ground-level ozone and particulates. Together, these contaminants combine to give southern Ontario, or more precisely the Windsor-Quebec corridor, the worst air quality problems in Canada. Other problem areas are the Lower Fraser Valley in British Columbia and the south Atlantic provinces region (10) (Figure 1).

Ground-level ozone, sulphur dioxide, nitrogen dioxide and particulates have been of greatest interest to health researchers because of their effects on the cardiorespiratory system. The OMA selected these priority pollutants for study based upon their known health effects.

Ozone: Ground-level ozone, as opposed to the natural stratospheric protective layer of ozone that screens out the sun's harmful ultraviolet rays, is a gas that is formed when its air pollution precursors, oxides of nitrogen, oxygen and volatile organic compounds (VOCs), interact in the atmosphere in the presence of sunlight. Nitrogen oxides are emitted from the combustion of fuels, mainly from transportation vehicles such as heavy duty diesel vehicles, but also from coal-burning power plants and natural gas processing. VOCs are also produced by motor vehicle exhaust and industrial processes, and from the evaporation of solvents, oil-based paints and gasoline from gas pumps. However, approximately half of the VOCs found in Canada are from natural sources such as trees (10).

Particulate matter and acid aerosols: Particulate matter and acid aerosols are fine solid or liquid particles produced 
by the combustion of fossil fuel, including emissions from diesel engines, coal-burning power plants, cement manufacturing plants, mining operations, residential wood combustion, and dust emissions from fields and roads (11). Because of their small diameter, less than $10 \mu \mathrm{m}\left(\mathrm{PM}_{10}\right)$ or less than $2.5 \mu \mathrm{m}\left(\mathrm{PM}_{2.5}\right)$, particulates remain suspended in air and when inhaled may penetrate deep into the airways. $\mathrm{PM}_{10}$ varies in chemical composition spatially and from day to day, but those with a large acidic fraction, called acid aerosols (mostly sulphates from burning fossil fuels), are likely to be the most harmful to the bronchioles and alveoli (10).

Epidemiological studies have reported on inhalable particle $\left(\mathrm{PM}_{10}\right)$ concentrations. Recent research, however, has focused on respirable particles or fine particles $\left(\mathrm{PM}_{2.5}\right)$.

Acid aerosols are essentially particles that contain acid, and are not traditionally monitored routinely to the same extent as other pollutants such as ozone. However, routine measurements have been made of sulphate levels, which correlate to some degree with acid measurements (12). Acid aerosols are acidic particulates (eg, sulphates - often referred to as particulate sulphates). There is no known safe level for exposure to sulphate particles (2). Acid aerosols have been linked to respiratory irritation and disease, corrosion of materials, and reduction of visibility (13), and are the precursors of acid rain.

In terms of air quality, Canadians consider visibility to be a marker of their quality of life. The public understands that if the air looks bad, it is likely harmful. At times, however, adverse health impacts may still be associated with air that appears 'clean'. Since the industrial revolution, human activities have increased the concentration of ground-level ozone (14). Sulphate and other fine particles scatter and absorb light, thus reducing visibility. Models and measurements show that visibility in southern Ontario and Quebec is lowest where sulphate deposition is highest. The area of generally reduced visibility coincides with the area receiving most acid deposition. Research shows that acid aerosols are the dominant factor in most cases of poor visibility in eastern North America (15).

The Ontario problem: It is on hot summer days when air masses stagnate that smog episodes occur, with smog blanketing large areas of Ontario, both urban and rural, for several days at a time. Levels are usually highest in the afternoon and early evening. Although pollutants are produced by local emission sources, transboundary transport from Ohio and other midwestern American states contributes significantly (more than 50\%) to ozone, particulate matter and acid aerosol levels in southwestern Ontario. Levels are highest in the Windsor-Quebec corridor and along the Lake Huron shoreline (10).

Environment Canada issues smog advisories when ozone levels are expected to exceed a specified level of $82 \mathrm{ppb}$. The advisories include both environmental information (eg, description of pollution sources) and health information to advise the public on the possible health risks associated with smog exposure (2). In 1993 and 1994, four advisories were issued - two in Saint John, New Brunswick and one each in southern Ontario and the Greater Vancouver Regional District, British Columbia. As Figure 1 shows, a significantly greater number of episodes of elevated ground-level ozone concentrations occurred in these areas in previous years (16).

Electricity can be produced in a number of different ways, for example, nuclear reaction, water power and burning of fossil fuels. In the regions under study (Ontario, eastern Canada, Ohio Valley/Great Lakes, and northeast United States), more than $96 \%$ of the coal-fired electricity generating stations are located in the United States. The generation of electricity across North America is evolving from being based on utility monopolies to a deregulated, competitive marketplace. A principal concern is the potential increase in the use of coal to generate low cost electricity, with resulting increases in the emission of pollutants such as sulphur dioxide, nitrogen oxides, particulate matter, mercury and carbon dioxide. In Ontario, coal-fired electric stations are major emitters of these pollutants. Due to the long range transport of many air pollutants from tall utility smokestacks, any increase in the use of coal in the Ohio Valley/Great Lakes states region will affect all areas to the east and northeast, which includes Ontario, Quebec and the American northeast and Atlantic Canada. The Great Lakes basin is particularly vulnerable to toxic fallout from increased air emissions (4).

There is a need to improve the quality of gasoline sold at the province's pumps. The sulphur levels in gasoline and diesel in Ontario are the highest in the country and among the highest in the developed world at 579 parts per million (ppm) in gasoline and diesel fuels of 2620 ppm off-road (17). By comparison, California, a state that has acted aggressively to reduce air pollution, limits sulphur in gasoline to $30 \mathrm{ppm}$ (18). High sulphur gasoline leads to increased amounts of nitrogen oxides, and more sulphur dioxide and sulphates (extremely small acidic particles that become imbedded deep in the lung tissue).

\section{ADVERSE HEALTH IMPACTS OF AIR POLLUTION}

In a review of evidence for the Canadian Smog Advisory Program, two expert panels (16) concluded that health and health care system effects of ground-level ozone at levels that occur in Canada include lung inflammation, decreased lung function, airway hyper-reactivity, respiratory symptoms, possible increased medication use and physician/emergency room visits among individuals with heart or lung disease, reduced exercise capacity, increased hospital admissions and possible increased mortality. Similar effects were thought to occur in association with airborne particles, with the exception of inflammatory changes and with the additional effect of increased school absenteeism. At the time the review was conducted (before 1995), poor data on individual exposures were identified by the expert panels as a limitation of studies on hospital admissions and mortality.

More recent studies, however, show associations between increased hospital admissions and mortality, and air pollutants. Several studies specific to the Utah Valley (known for the low smoking rates of its residents, low levels of ozone and acid aerosols and high levels of $\mathrm{PM}_{10}$, and the presence of an 
operating steel mill) have evaluated associations between various indicators of health and $\mathrm{PM}_{10}$ pollution. Taken together, they suggest a coherence of associations across various health end-points for a specific location and population. Health effects found to be associated with elevated $\mathrm{PM}_{10}$ pollution included increased respiratory hospital admissions and increased mortality, especially respiratory and cardiovascular mortality. It is improbable that these apparent air pollution-related health effects were due to methodological bias; in addition, confounding factors such as cigarette smoking and weather were ruled out by researchers (19).

\section{SUMMARY OF RESEARCH ON HEALTH EFFECTS OF AIR POLLUTION}

Expert panels of the American Thoracic Society (20) describe the potential health effects of air pollution as occurring in a logical 'pyramid' ranging from severe uncommon events (eg, death) to mild common effects (eg, eye, nose and throat irritation that may interfere with normal activity such as driving a car, if severe) and measurable changes of lung function that are asymptomatic, due to the naturally large lung reserve in healthy individuals. This 'health effects pyramid' illustrates the general correlation of the severity of documented health effects with the strength of the scientific evidence available $(16,20,21)$. Thus, while individual severe health events are less common, there is a large overall impact on health and well-being because of the large number of people involved (Figure 2) (16).

Immunological effects: Pollutants may indirectly cause a wide spectrum of immunological disorders. For example, an aerosol of sulphuric acid of low concentration produces little or no inflammation of the lung, but the resulting acidity in the airway accentuates the effects of ozone (22).

Individual reactions: Individual reactions vary widely, but even healthy outdoor workers show a measurable decrease in lung function when exposed to low levels of ozone.

While it is commonly assumed that individual reactions to pollutants are the same, research indicates that individual reactions vary widely, and once an individual reacts to a pollutant, this recurs with further exposures. Both healthy and ill individuals may be affected by certain air pollutants. Sensitive subgroups are those with asthma, cigarette smokers, the elderly, infants, persons with coronary artery disease and persons with chronic obstructive pulmonary disease (COPD) (23). Although healthy nonsmokers show a wide range of lung function changes in response to ozone exposure, any response shown by an individual is consistent with his or her responsiveness to ozone on subsequent re-exposure (24).

Individual reactions to air pollutants depend upon the type of pollutant, how much of the pollutant is present, the degree of exposure, and the types and levels of individual activity; individuals working or exercising outdoors have the greatest exposure. Results of a study of berry pickers in the Fraser Valley of British Columbia indicate that even for individuals living and working in areas of relatively low ambient ozone concentrations (range 13 to $84 \mathrm{ppb}$ ), ozone exposures were substantial enough to be associated with a decrease in lung

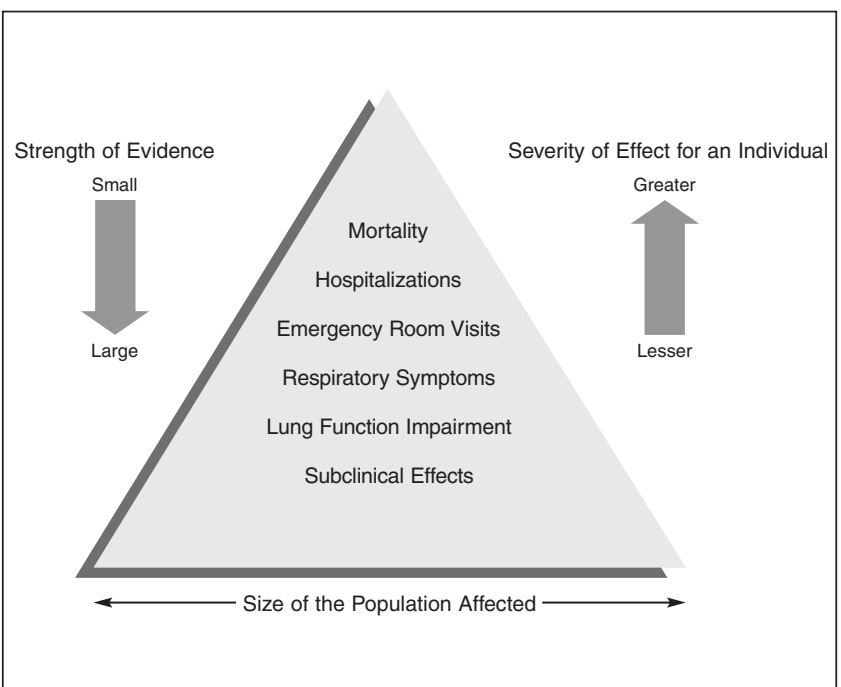

Figure 2) Health effects pyramind showing the cascading effect. Adapted from reference 16 and American Thoracic Society, 1985.

function during the course of a day, which persisted at least until the following day (25). Interestingly, the upper range of ozone concentration found in this study was only $2 \mathrm{ppb}$ higher than the current standard in Canada. These results are significant because individuals may be affected by air pollution without displaying symptoms; air pollutants affect everyone in the long run, and there does not appear to be a 'threshold' level for ground-level ozone or particulates below which no health effects are observed.

Respiratory infections: Air pollution appears to aggravate lung infections, possibly by reducing the body's ability to fight infection (2); a relationship between air pollution and impaired resistance to respiratory infection, shown in animals, has also been seen in studies of humans. Research studies indicate there is an association between increased acute lower respiratory tract disease, such as acute bronchitis and pneumonia, and air pollution $(26,27)$. These relationships are of particular public health significance because infections and allergies of the respiratory tract account for a major portion of total acute illness in the general population, and exact a large economic toll in terms of time lost from school or work, visits to doctors and admission to hospitals. Other possible factors, such as social class or area differences in residential mobility, could not explain all the excess respiratory illness rate in children seen in areas with high pollution (28).

Asthma exacerbations: Asthma is made substantially worse by current concentrations of particles and ground-level ozone.

The literature on asthma epidemiology is very extensive. Patterns of medication and health care practices (as shown by differences in mortality rates among countries) are believed to play a role in mortality effects. There have been indications that prevalence may have increased (29). In Canada, there has been a marked increase in hospital admission rates for asthma (30).

Asthma is a complex disease that is multifactorial: in most cases, there is a genetic predisposition and exposure to an en- 
vironmental allergen. There is good reason to be suspicious of the role of air pollutants, but proof that they cause increasing asthma prevalence is lacking (29). However, in a study by Thurston et al (31) air pollution was found to be significantly and consistently correlated with acute asthma exacerbations, chest symptoms and lung function decrements in asthmatic individuals. Most affected subjects had moderate to severe asthma. The pollutant most consistently associated with adverse health effects was ozone, although associations with sulphates and hydrogen ions suggested a possible role for fine particles as well. Ozone, together with acid aerosols, may well be playing a combined role in exacerbations of asthma, causing airway inflammation. Strong evidence from North America has shown that the increased number of emergency visits for asthma and acute admissions for respiratory illness are related to ground-level ozone generated from oxides of nitrogen and hydrocarbons. This is hardly surprising because ozone at very low concentrations induces lung inflammation and potentiates the effect of any allergen encountered subsequently (32). At present, only a limited number of studies have examined the effect of acute exposure to ozone or nitrogen dioxide on the response to inhaled allergen in human subjects (33). Molfino and colleagues (34) found that the response to inhaled allergen after $1 \mathrm{~h}$ exposure to air with ozone concentrations of $0.12 \mathrm{ppm}$ was significantly greater than the response to an allergen after air without ozone in six of seven subjects.

Chronic effects: Long term exposure to air pollutants is associated with decreased lung function and increased cityspecific mortality rates. In a study of the effects of long term exposure to air pollutants in eight areas of Switzerland, air pollution from fossil fuel combustion, the main source of air pollution, was associated with decreased lung function (35). Studies from the United States show similar chronic effects. A 14- to 16-year follow-up of 8111 adults participating in the Harvard Six Cities Study showed increased city-specific mortality rates after adjusting for individual risk factors. Adjusted death rates appeared to increase most consistently with air concentrations of particles less than $\mathrm{PM}_{2.5}$; this association was not explained by tobacco use, occupational exposure or a history of chronic disease (36).

Excess cardiorespiratory mortality: Mortality is only the tip of a much larger morbidity problem. The air pollution disaster in London, England in December 1952 established that very high levels of particulate-based smog can cause dramatic increases in daily mortality. As the month began, stationary air resulted in a temperature inversion in the Thames Valley and an extremely rapid increase in particulate-based smog from direct burning of coal for space heating. The rapid increase in pollution was followed, with a lag of less than one day, by an increase in the daily death rate in London, which peaked at 500 from a customary level of approximately 200 daily deaths. No other epidemics could account for this increase. Mortality also increased in other urban areas of the United Kingdom in which the increased pollutant concentrations was much less than in London (37). Daily respiratory disease admissions to hospitals in greater London peaked at
460 cases, compared with an average of 175 cases/day immediately preceding the fog (38).

A rapidly evolving area of research has found provocative new epidemiological information linking particle exposure, substantially lower than those seen in London in 1952 but commonly occurring in American cities (37), with mortality in older people who have pre-existing cardiorespiratory disease (5).

Numerous studies conducted worldwide show a significant acute health consequence of exposure to particles, and this pollutant may be responsible for between $1 \%$ and $10 \%$ of all nonaccidental deaths. Recent data, obtained in six eastern American cities, suggest that increased daily mortality is specifically associated with the concentration of fine particles in the air $\left(\mathrm{PM}_{2.5}\right)$. The implication is that remedies should aim to reduce levels of fine particles in the air by focusing on their sources, including direct emissions and secondary reactions of combustion-related air pollutants (39).

Studies conducted locally demonstrate similar results. In Toronto, Ontario, strong associations were observed between premature mortality due to respiratory disease and levels of airborne particles, ground-level ozone and nitrogen dioxide (40). In this study, a $2 \%$ to $4 \%$ excess of respiratory deaths could be attributed to pollutant levels. Similar associations were observed for cardiovascular deaths. These data are consistent with other studies in North America and Central America.

An association between inhalable particulates and increased mortality was found in metropolitan areas in North America, including Toronto and Detroit, Michigan. Studies showed that an increase of $10 \mu \mathrm{g} / \mathrm{m}^{3}$ could increase the total mortality rate by $1 \%$ (41). The Ontario Smog Plan Workgroup (42) has estimated that approximately 1800 premature deaths and 1400 hospital admissions per year in Ontario are caused by the effects of inhalable particles.

Data from 12 European cities showed that increases in sulphur dioxide and particulate matter were associated with increased total mortality. An increase of $50 \mu \mathrm{g}$ per cubic metre in sulphur dioxide or black smoke was associated with a $3 \%$ increase in daily mortality (both cardiovascular and respiratory), and the corresponding figure for $\mathrm{PM}_{10}$ was $2 \%$. The effects of the two pollutants seem to be independent. The authors of the study noted that the consistency of the results in western European cities with wide differences in climate and environmental conditions suggests that these associations may be causal. Although the reported relative risks are small, the short term effects of air pollution are not a trivial public health problem if the omnipresence of air pollution exposure is taken into account. From a population health perspective, exposure of a large number of people to a small risk can result in more illness in the population than exposing a small number of people to a large risk. In short, researchers conclude that even the current low levels of sulphur dioxide and particles have detectable short term effects on health, and that further reductions are needed (43).

In the case of $\mathrm{PM}_{10}$ particles, an understanding of the biological mechanism is missing. Opinion is divided as to 
whether this should prevent the conclusion that the relation between $\mathrm{PM}_{10}$ particles and mortality is causative - a not uncommon problem (44). Gamble and Lewis (45) (who received partial funding by the Institute of Petroleum, London, England) reviewed recent epidemiological studies about the health effects, including mortality and morbidity of $\mathrm{PM}_{10}$ particulates, to evaluate whether criteria for causality were met and concluded that they were not. They have questioned the validity of using ecological studies to test hypotheses and suggested that associations were statistical rather than cause-effect, and that the strength of the association was weak and confounded by other pollutants, making it impossible to separate individual pollutant effects (45). A central methodological issue in studies of air pollution and daily counts of deaths or hospital admissions is the control for seasonal variations. The effect of changes in the weather is probably nonlinear, and adequate methods are necessary to adjust for this. However, several methods exist to control for weather and seasonal variations while examining the associations between air pollution and daily counts of mortality and morbidity. In each case, care and judgement are required (47).

It has been argued that hospital records are too unreliable to be used in epidemiological studies of admission rates and air pollution. However, a study indicates that such records are reliable enough; Delfino et al (48) in Quebec showed that there was $95 \%$ congruence between the diagnosis of asthma among in-patients and subsequent confirmations of their diagnosis after a detailed investigation by the hospital. The diagnoses are communicated to a computerized database. This high confidence level was possible because of the high quality of Canada's health information system.

In recent years, there has been a dramatic increase in the use of numerical situational models in the earth sciences to evaluate large scale or complex physical processes. In some cases, the predictions generated by these models are considered as a basis for public policy decisions such as air pollution and daily deaths. Oreskes and colleagues (49) argue that verification and validation of numerical models of natural systems are impossible. This is because natural systems are never closed and model results are always nonunique. Models can only be evaluated in relative terms, and their predictive value is open to question. The primary value of models is heuristic: models are representations, useful for guiding further study but not susceptible to proof.

The attacks and counterattacks in the scientific literature about the issue of causality demonstrate how hard it has been to prove unequivocally that air pollution can cause increases in daily mortality rates. There is discussion about exactly which pollutant produces health effects and the severity of those effects. In an attempt to resolve the controversy, Schwartz (37) employed meta-analysis to examine 12 studies. He found that airborne particle concentration was a small but significant risk factor for elevated mortality. The relative risk was 1.06 (95\% CI 1.05 to 1.07). Taken together, the studies presented a coherent picture of associations with a full range of respiratory outcomes, including mortality, and concluded that the most reasonable interpretation of results is that the association is causal.

Effects of air pollutants on children: Children represent the largest subgroup sensitive to adverse effects of air pollution for several reasons. First, differences in pulmonary anatomy and physiology of children lead to inhalation and retention of greater quantities of particles per unit body weight than adults. Second, children show an increased susceptibility to respiratory infections. Third, there may be a developmental susceptibility; animals, when exposed to high levels of ozone, show permanent decreases in the number of respiratory bronchioles formed postnatally (50). Finally, children are most at risk from exposure to ozone because they are active outside during the summer, when ozone levels are at their highest. Increased morbidity from illnesses such as bronchitis and indirect health effect indicators such as school absences occur in both rural and urban Ontario communities.

Data obtained from six summer camp studies carried out by three separate investigative groups, including two studies in Ontario, confirm a measurable population average mean decline in forced expiratory volume in $1 \mathrm{~s}\left(\mathrm{FEV}_{1}\right)$ associated with ozone exposures that was qualitatively similar to that reported in laboratory studies. These results raise the concern that other effects observed in laboratory studies such as pulmonary inflammation may also occur in young people exposed to ozone (51).

Income affects environmental health. Results of a southern California study indicate that ozone exposure is highest for children six to 11 years old, and demonstrates the importance of a socioeconomic perspective. While ozone exposure differences by race and ethnicity have diminished over time, on average, low income areas may experience a higher number of per capita hours of excess ozone exposure than high income areas, suggesting that environmental health risks may be systematically higher for low income groups (52). This observation may be true in the United States, but paradoxically it may not be so in Ontario. Because of the scavenging effect of nitrogen oxides, ozone levels may well be higher in suburban or rural areas than they are in the downtown cores of Ontario's major cities (53).

There are indirect indicators of the effects of air pollution on children. Ransom and Pope (54) showed convincingly that school absences in grades 1 to 6 were significantly associated with $\mathrm{PM}_{10}$ levels. The response was greater in those in grades 1 to 3 (six to nine years old) than in the older children. The authors concluded that weather variables were unlikely to have been responsible for the findings.

In a study of respiratory health effects of exposure to acidic air pollution among 13,369 Caucasian children, aged eight to 12 years from 24 communities in the United States and Canada (including children from rural Ontario between 1988 and 1991 [55]), children living in the community with the highest levels of airborne acids were significantly more likely to report at least one episode of bronchitis in the previous year compared with children living in the least-polluted community. Reported bronchitis was associated with elevated levels of airborne acids for children living in a no- 
nurban environment. Potential confounding factors such as history of allergies and current smoking in the home were considered. These data indicate that chronic exposure to acid aerosol pollution may have observable negative consequences on the health of children. Although the long term consequences of bronchitis in these children remain unclear, respiratory illnesses in childhood may be a risk factor for development of COPD, which can be fatal. These children also may be at a higher risk from other environmental or respiratory pollutants and occupational exposures later in life. In this same group of well children, a modest but significant reduction in pulmonary function level was shown among children living in communities with higher levels of respirable particulates, including directly measured airborne acids. The continued exposure of these children may put them at a disadvantage in the future (56).

When all the data are taken together, there is no doubt that relatively low levels of pollution are responsible for increased morbidity in children, particularly the pollution associated with uncontrolled coal burning (57).

Dr Phillip Landrigan, chair of community medicine at Mount Sinai Hospital, New York, New York, has stressed that degradation of the environment results in disease, particularly in children.

Too frequently the environmental movement is seen as people worried about trees and the disappearance of species and is often seen as elitist upper middle class. But there are differential vulnerabilities. All kids are not equally affected. Minority inner-city children are the most heavily impacted by the exposure to (environmental) toxins, and when this is coupled with poor nutrition and housing, it's a prescription for disease. (58)

Effects of air pollutants on the elderly: The elderly and those with cardiac or respiratory diseases, such as asthma, emphysema and chronic bronchitis, are especially sensitive to air pollutants. The elderly population, already large, will continue to grow dramatically over the next decade. This demographic trend will result in an increasingly large population prone to the health effects of air pollution. By the year 2030, there will be eight million Canadians over the age of 65 years, nearly one-quarter of the population (59). People aged 75 years and over are much more likely than younger adults to have health problems and use health care services (60); some of these problems and increased usage will be attributable to air pollution.

Age and health status are important predictors of an individual's reaction to air pollutants. In general, the more susceptible populations are the elderly and those with cardiac or respiratory diseases such as asthma, emphysema and chronic bronchitis (2). In 1993, ground-level ozone, particulate matter $\left(\mathrm{PM}_{10}, \mathrm{PM}_{2.5}\right)$ and the sulphate fraction of $\mathrm{PM}_{2.5}$ were all positively associated with respiratory emergency room visits for patients older than 64 years in Montreal, Quebec. Therefore, studying the physiological effects of air pollutants on older individuals is important, not only for biological reasons, but also because of the significant health care re- sources that will be used by this group, given their growing proportion in the Ontario population (61).

Health effects and air pollution - Conclusions: Groundlevel ozone, acid aerosols and particulates have created a serious health problem in both Canada and the United States.

- There does not appear to be a threshold level for ozone or particles below which no health effects are observed. No known harmful effects of ozone appear with an index of less than $15 \mathrm{ppb}$; therefore, it is important to achieve this acceptable standard.

- Children and the elderly, both those who are well and those with pre-existing cardiorespiratory disease, are particularly sensitive to air pollutants. This increased morbidity, manifested by conditions such as reported bronchitis, were associated with elevated levels of airborne acids for children living in rural Ontario. Indirect adverse health indicators such as school absences were associated with particulate matter.

- Air pollution appears to aggravate lung infections.

- Even healthy outdoor workers show a measurable decrease in lung function when exposed to low levels of ozone.

- Asthma is made substantially worse by current air concentrations of particles and ozone.

- Long term exposure to air pollutants is associated with decreased lung function and increased city-specific mortality rates.

- Numerous studies conducted worldwide show a significant acute health consequence of exposure to particulates, and this pollutant may be responsible for between $1 \%$ and $10 \%$ of all nontrauma deaths. A Toronto study, for example, indicated that a $2 \%$ to $4 \%$ excess of respiratory deaths could be attributed to pollutant levels.

\section{EFFECTS OF AIR POLLUTION ON THE HEALTH CARE SYSTEM}

While health care professionals may be mainly concerned about the effects of pollutants on the health of their patients, a complete analysis must also take into account the impact of these air pollutants on the institutional health care system and the economy. The main concerns fall into three groups, increased emergency room visits, increased hospital admissions and negative economic impacts.

It is important to note that the vast majority of asthma is treated in the community by primary care physicians. In the community setting, there is no method to quantify the frequency and severity of asthma exacerbations. Hence, this burden of illness may be greater than revealed by hospital admission and emergency room visit rates.

Increased emergency room visits: Increased use of health care is an important issue, particularly in an era of cost containment. An association was found between acute respiratory admissions to 79 acute care hospitals in southern Ontario and ozone levels (62). A later and more detailed analysis confirmed the association between summer ozone levels and hospital admissions for acute respiratory disease 
and showed that the association was observed for both sulphates and ozone (63). It was shown that asthma admissions for children for a period of $24 \mathrm{~h}$ after ozone had exceeded the Canadian objective of $0.08 \mathrm{ppm}$ for $1 \mathrm{~h}$ were consistently elevated compared with admissions on all summer days (64). In this and similar studies, it has proved difficult to separate the effects of the individual pollutants because, in this region, they commonly rise and fall together (65). The association of hospital admissions with sulphate levels in southern Ontario was confirmed by Plagiannakos and Parker (66). These two analyses in southern Ontario, though planned and conducted independently, reinforce each other in terms of the relationship they established between morbidity indices and sulphates (67).

Similar findings have been reported for emergency or urgent daily respiratory admissions to all 168 acute care hospitals in Ontario below the 47th parallel (representing the majority of Ontario hospitals) over a six-year period from January 1983 to December 1988. Summer respiratory admissions were closely associated with ozone levels, and among infants, $15 \%$ of summer admissions were pollutant-associated, whereas among the elderly only $4 \%$ were (68).

A study from the Saint John, New Brunswick area (69) showed that elevated concentrations of ground-level ozone were associated with increases in emergency department visits and asthma visits increased by $33 \%$ two days after the daily ozone maximum exceeded $75 \mathrm{ppb}$. This finding is especially significant because the majority of ozone levels recorded in this study were below the $1 \mathrm{~h}$ national standard for ozone of $82 \mathrm{ppb}$.

Associated with increased emergency room visits are effects on quality of life and the economic burden in relation to episodes of cardiorespiratory disease. Outcomes commonly reported are increases in medication use, reduced activity, increased days spent in bed, increased physician office visits and increased out-of-pocket expenses for items such as medication, parking fees, workdays lost and child care for siblings (70).

Increased hospitalizations for exacerbations of chronic respiratory diseases: Increased hospitalizations represent an outcome measure or health indicator of air pollution. Burnett et al (71) found an association between low levels of ozone and respiratory diseases severe enough to require hospitalization in 16 Canadian cities representing 12.6 million people. The association between ozone and respiratory hospitalizations varied among cities. Particulate matter and carbon monoxide were also positively associated with respiratory hospitalizations. These results suggest that ambient air pollution, at relatively low concentrations of pollutants, is associated with excess admissions to hospital for respiratory diseases in populations experiencing diverse climates and air pollution profiles.

An analysis of 22 acute care hospitals in Toronto indicated that exacerbations of pre-existing respiratory disease, including asthma, were associated with community exposures to elevated levels of summertime haze, ground-level ozone, and acid air pollution. On average, summertime haze was as- sociated with $24 \%$ of all respiratory admissions $(21 \%$ with ground-level ozone, $3 \%$ with acid air pollution). On peak pollution days, however, aerosol acidity yielded the highest relative risk (RR) estimates (eg, $\mathrm{RR}=1.5 \pm 0.25$ at 391 nmole $/ \mathrm{m}^{3} \mathrm{H}^{+}$, and summertime haze was associated with roughly half of all respiratory admissions (38). Results of this paper must be viewed in light of the conclusions of its companion paper (72) concerning the nature and origins of acid summer haze air pollution. Together, these two studies suggest that not only are acidic summertime haze air pollutants being transported in the atmosphere to Toronto from upwind regions of the United States, but also that this transported pollution has measurable adverse health consequences in that city. Thus, to ameliorate this environmental health problem in Toronto and its vicinity, cooperation between the United States and Canada is clearly required. Of particular relevance to this issue is the fact that the Great Lakes basin has consistently high levels of certain air pollutants because of wind patterns, geographic location and sources of pollution. Annual average ozone levels in the basin have been consistently above the national objective of $15 \mathrm{ppb}$ for the past several years. In general, levels of particulates and sulphates have not declined over the same period (2).

Economic impacts: Economics describes the use of society's resources. Resources used for one purpose are unavailable for another, a concept known as opportunity cost. The economic burden of ill health is measured in terms of direct costs (eg, hospitalizations) and indirect costs (eg, loss of work or school days, or restricted activity days) (8).

Assessing the economic impact of air pollution is a complex task. Once the simpler measures have been taken to limit the emission of pollutants from single sources, further control measures are more costly and more difficult to implement. Specifically, reducing nitrogen dioxide emissions from cars and trucks is not simple, and reducing $\mathrm{PM}_{10}$ may prove to be even more difficult. In this situation, there should be an expectation that current economic impact of air pollution will be calculated before costly and difficult control measures are instituted. For example, is $\mathrm{PM}_{10}$ likely to be the same everywhere? How should the cost of a premature death be evaluated in relation to age? Is death accelerated by only a few days in the majority of instances? These and other questions have to be answered before any estimate can be produced (73).

Increased daily mortality rates, however, should not be the only measure of the negative health effects of air pollution. For example, asthma confers a long term state of susceptibility, with effects on emotional well-being and social interaction involving not only the patient, but often also a caregiver. Depicting asthma merely as discrete episodes of shortness of breath may lead to an undervaluation of its effects (74).

Industrial interests, capable of exerting substantial economic pressure, will attempt to minimize the importance of effects such as the increased risk of lower respiratory infections among children. For this reason, economic calculations may be useful for reminding legislators that there is further work to be done. Some believe that there is a conflict between pollution control and economic development. It was formerly ta- 
TABLE 1

Selected reduced annual health effects in morbidity and mortality by 2015 associated with smog scenarios for Ontario

\begin{tabular}{|c|c|c|c|c|c|c|c|c|}
\hline \multirow[b]{3}{*}{ Scenarios } & \multicolumn{8}{|c|}{ Reductions in selected morbidity effects } \\
\hline & \multicolumn{2}{|c|}{ Reductions in mortalities } & \multicolumn{2}{|c|}{ Hospital admissions* } & \multicolumn{2}{|c|}{ Adult chronic bronchitis } & \multicolumn{2}{|c|}{ Symptom days (000s) } \\
\hline & $\mathrm{O}_{3}$ & IP & $\mathrm{O}_{3}$ & IP & $\mathrm{O}_{3}$ & IP & $\mathrm{O}_{3}$ & IP \\
\hline $\begin{array}{l}\text { Scenario 1: } \\
\text { Existing plus readily } \\
\text { available reductions, relative } \\
\text { to a base of unreduced } \\
\text { emissions in the year } 2015\end{array}$ & 2 to 4 & 59 & 11 to 23 & 46 & NA & 394 & 127 to 270 & 1496 \\
\hline $\begin{array}{l}\text { Scenario } 2 \text { : } \\
45 \% \text { reductions of } 1990 \\
\text { NOx and VOC emissions, } \\
\text { relative to a base case of } \\
\text { unreduced emissions in the } \\
\text { year } 2015\end{array}$ & 4 to 10 & 118 to 173 & 28 to 58 & 91 to 137 & NA & 797 to 1169 & 315 to 661 & $\begin{array}{c}3023 \text { to } \\
4436\end{array}$ \\
\hline
\end{tabular}

Inhalable particulate (IP) values are based on reductions in secondary formation of IP, due only to decreases in nitrates and secondary organic aerosols. Not all health effects are shown in this table. ${ }^{*}$ Respiratory for ozone $\left(\mathrm{O}_{3}\right)$, cardiac plus respiratory for IP; ${ }^{\dagger}$ Sum of asthma, restricted activity and acute respiratory days. NA Not applicable; $N O_{x}$ Nitrogen oxides; VOC Volatile organic compounds

\section{TABLE 2}

Total annual monetary values of reduction in morbidity and mortality effects by 2015 associated with smog scenarios for Ontario

\begin{tabular}{lccc}
\hline Emission reduction scenarios & $\begin{array}{c}\text { Value of reduced mortality } \\
\text { effects (\$million/year) }\end{array}$ & $\begin{array}{c}\text { Value of reduced morbidity } \\
\text { effects (\$million/year) }\end{array}$ & $\begin{array}{c}\text { Total reduced morbidity and } \\
\text { mortality effects (\$million/year) }\end{array}$ \\
\hline $\begin{array}{l}\text { Scenario 1: } \\
\text { Existing plus readily available }\end{array}$ & 240 to 249 & 157 to 161 & 398 to 410 \\
reduction, relative to base case of & & \\
unreduced emissions in the year & 490 to 730 & 319 to 473 \\
2015 & & \\
Scenario 2: & & \\
$45 \%$ reduction of 1990 NOx and & & \\
VOC emissions, relative to a base & & \\
case of unreduced emissions in \\
the year 2015
\end{tabular}

The monetary value estimates are not discounted to reflect the reduced value people place on future benefits. If these values are to be compared explicitly with more immediate (1996 to 2000) investments in abatement or prevention, the value of any future benefits should be discounted. $\mathrm{NO}_{x}$ Nitrogen oxides; VOC Volatile organic compounds

ken for granted that the costs of better air pollution control were a burden on industry and interfered with prosperity and full employment. But few countries take into proper account the long term costs and inefficiencies that follow human disease, in adults and children, related to air pollution such as higher taxes to subsidize increased health care costs (73).

Clean air is common property, yet zero man-made ozone concentrations are unlikely to be a viable option, because of other public and private priorities. A full economic appraisal for setting an optimal air quality goal for any substance is therefore required to determine the value of the health and other benefits, such as enhanced commercial crop yields expected from varying levels of abatement from minor to high emission reductions. These would be compared with the expected costs of achieving each level of abatement related to monitoring and enforcement (74).

It should be noted that the economic valuation exercises are quite controversial, but in the spirit of public disclosure, the numbers are presented here. To calculate the health, environmental and economic benefits of reducing the precursors of ozone (one component of smog), the Ontario MOE (41) started from a baseline that assumed that no reduction activities take place between 1990 and 2015. If that were the case, it is projected that by year 2015, emission levels would reach 933 kilotonnes/year of nitrogen oxides and 1215 kilotonnes/year of VOCs. From this baseline, the projected benefits of reducing emissions of these ozone precursors was calculated using two scenarios: scenario 1 used existing and readily available reductions, and scenario 2 used a $45 \%$ reduction from 1990 levels of nitrogen oxides and VOC emissions in Ontario. Table 1 shows that with committed and readily available efforts to reduce nitrogen oxides and VOC emissions as indicated in scenario 1, there could be as many as 63 fewer deaths a year by 2015 due to decreases in ozone and inhalable particulate exposures. Table 2 summarizes the range of total estimated annual monetary values associated with reduced mortality and morbidity for Ontario if reduction goals are achieved by 2015. By 2015, in Ontario, total monetary values that may be attributed to reduced mortality and morbidity range from $\$ 398$ million to as much as $\$ 1.2$ billion. Reductions in human health effects associated with sulphur dioxide emission reduction scenarios are listed in Table 3. This table 


\begin{tabular}{|c|c|c|c|c|}
\hline & $\begin{array}{c}\text { Scenario } 1 \\
25 \% \mathrm{SO}_{2} \text { reduction } \\
\text { Canada and US }\end{array}$ & $\begin{array}{c}\text { Scenario } 2(\mathrm{a}) \\
50 \% \mathrm{SO}_{2} \text { reduction } \\
\text { Canada and } 50 \% \text { in US }\end{array}$ & $\begin{array}{c}\text { Scenario } 2(b) \\
50 \% \mathrm{SO}_{2} \text { reduction } \\
\text { Canada only }\end{array}$ & $\begin{array}{c}\text { Scenario } 3 \\
75 \% \mathrm{SO}_{2} \text { reduction } \\
\text { Canada and US }\end{array}$ \\
\hline Mortality & 200 & 550 & 200 & 830 \\
\hline Airway obstructive disease (cases) & 710 & 1920 & 730 & 2900 \\
\hline Hospital admissions* & 230 & 630 & 240 & 950 \\
\hline Emergency room visits & 560 & 1530 & 580 & 2300 \\
\hline Asthma symptom days & 77,300 & 210,070 & 79,300 & 316,900 \\
\hline Restricted activity days & 110,270 & 299,500 & 113,500 & 451,800 \\
\hline Acute respiratory symptom days & $2,691,150$ & $7,313,600$ & $2,759,900$ & $11,033,500$ \\
\hline Child bronchitis (cases) & 9600 & 26,140 & 9800 & 39,400 \\
\hline Total benefits (\$millions) & $\$ 210-\$ 2,000$ & $\$ 590-\$ 5,400^{\dagger}$ & $\$ 220-\$ 2,000$ & $\$ 890-\$ 8,000$ \\
\hline
\end{tabular}

${ }^{*}$ Respiratory and cardiac hospital admissions

illustrates what is possible with emission reduction and the cost involved with each scenario. For example, a 75\% sulphur dioxide reduction in both Canada and the United States will achieve a benefit of $\$ 890$ million to $\$ 8$ billion (15).

In summary, the physicians of Ontario consider this health problem to be costly. Although economic analysis is not the purview of physicians, the OMA believes that this issue deserves study by experts in the field.

The health care system and air pollution - Conclusions: Increases in these air pollutants are linked to the following.

- Increased visits to doctors or emergency rooms and increases in medication use. For example, emergency or urgent daily respiratory admissions to 168 acute care hospitals in Ontario were closely associated with ozone levels.

- Increases in hospitalization for respiratory and cardiac disease. For example, a study in 16 Canadian cities found an association between low levels of ozone and respiratory diseases severe enough to require hospitalization.

- A large economic toll. For example, it has been estimated that approximately 1400 hospital admissions per year in Ontario are due to the effects of inhalable particulates alone (42). This calculation fails to account for patient and family costs such as out-of-pocket expenses and lost workdays.

\section{RECOMMENDATIONS}

It is clear that there is a broad range of adverse health effects from ground-level ozone, acid aerosols and particles, ranging from mild chronic illness to death. The sources of the pollutants that cause these effects are numerous and wellknown, including electric power generation, industrial, transportation and small individual sources.

Medical evidence reviewed in this paper clearly establishes the need for more stringent and mandatory emission reduction strategies. As part of this analysis, the OMA consulted experts and authors in this field, and has determined that there are several levels of recommendations to be made: items actionable by government, by the OMA as a group, by individual physicians, and by the public.
The OMA believes that public policies in this area must address both how much pollutant people are being exposed to and for how long, as well as the quantity of emissions from industrial and other sources. Tonne for tonne, emissions of ozone-smog pollutants have heavier health impacts on people in the area where they are released. But emissions from distant upwind regions can add to the harm from more local emission sources. For this reason, the only effective way to reduce ozone-smog and fine particulate matter is to reduce nitrogen oxide and sulphur dioxide emissions throughout eastern North America and to achieve strong controls on hydrocarbon emissions in the immediate vicinity of areas experiencing high ozone levels.

It is now well established that more than half of southeastern Canada's acid rain and related air pollution problems originate in the United States (15). Research has also demonstrated that point sources in Ontario (and possibly elsewhere in eastern Canada) contribute to pollution loadings both in the province itself and in the United States. Therefore, any recommended solutions to the air pollution problem in this province and elsewhere in Canada must include actions that need to be taken in both Canada and the United States.

It is also important to note that the American system for determining standards differs significantly from the Canadian system. The American approach depends on a combination of command-and-control regulatory strategies and market-based mechanisms, under which tonnage reductions and target dates are established, with associated legislation, regulations, timetables, emission credit trading mechanisms and noncompliance penalties. In contrast, the Canadian system tends frequently to be voluntary, with criteria or guidelines established for which there are no mandatory compliance dates or noncompliance penalties. Notable exceptions in the latter case include Ontario's countdown acid rain program regulations established in 1985.

While approaches to controlling air pollution in the United States include both ambient air quality standards and emission reduction strategies, Canadian jurisdictions do not generally set the same type of air quality standards as those found in, for example, the new American national ambient air quality standards approved last year. The OMA believes 
that mandatory air quality standards must be developed in Canada, at least for parts of the country like the WindsorQuebec corridor, which suffer from significantly elevated levels of exposure to ozone and other air pollutants.

Updating and formulating new Canadian air quality standards may be a time consuming process. The medical (and terrestrial and aquatic) evidence indicates that society does not have time to wait for the conclusion of an extended process to formulate exposure standards. Also, good information exists concerning levels of emission reductions that must be implemented in the near term if people are to avoid continuing adverse health effects from air pollutants. During the OMA's review of various air pollution control strategies and scenarios, it became clear that coal-fired power plants and motor vehicles produce most of the pollutants at issue. Key strategies must therefore concentrate on power plants and motor vehicles situated in both the American midwest and Ontario.

There are several pollutants for which emission reductions are necessary: sulphur dioxide, oxides of nitrogen from power plants, and nitrogen oxides and hydrocarbons from transportation sector emissions.

When making recommendations, the OMA is particularly concerned to reduce the impacts of air pollutants on children. The increase in rates of childhood asthma is in part related to air pollution levels, and it is known that children's lungs can be particularly susceptible to impacts from air pollution and other irritants such as second-hand smoke. Children's lungs are smaller, they breathe faster and the risks of negative effects are proportionately greater than for adults.

The balance of the recommendations below focuses on pollutants within two major sectors: the electricity generation sector (specifically coal-fired power plants) and the transportation sector. They have been selected from a review of recommendations made by the various agencies, and are those that the OMA feels a particular responsibility to support.

Coal-fired power plants produce two types of emissions that the research reviewed in this paper identified as major causes of the health effects under consideration: sulphur dioxide and oxides of nitrogen. Sulphur dioxide is a precursor of both acid rain and fine particles that have been identified as a major contributor to negative respiratory health effects. Nitrogen oxides are the precursor of both acid rain and ground-level ozone (and fine particles).

Action was taken in the mid-1980s to reduce sulphur dioxide significantly from Ontario power plants and nonferrous metal smelters, and the 1990 United States Clean Air Act mandated significant sulphur dioxide reductions from the electricity generation sector. A recent review by the Canadian Acidifying Emissions Task Group (15), however, clearly demonstrated that existing reductions have not been sufficient to alleviate either health or environmental damage from acid rain-causing emissions.

In light of the medical evidence, it is incomprehensible that the Ontario MOE apparently intends to allow a significant increase in emissions from Ontario Hydro and will not require emission controls comparable with those being pro- posed by the United States Environmental Protection Agency (USEPA) (75). While the emission rates of Ontario power plants are lower than many older (and higher polluting) American midwestern power plants, emission increases resulting from the nuclear shutdown will worsen local air quality. As noted earlier, impacts of provincial power plants on local air quality are, tonne for tonne, more significant than pollution from more distant sources. It should also be noted that Ontario Hydro's power plants contribute to acid aerosol loadings and ground-level ozone in the northeast United States.

As in the past, interested Canadian individuals and groups from the health, environment and other sectors need to be active at the USEPA and at other federal and state government agencies in order to make the case for further American emission reductions. This activity cannot be credible if the Ontario government allows sulphur dioxide and nitrogen oxides emissions from Ontario Hydro's plants to increase without any additional investment by the corporation in sulphur dioxide and nitrogen oxides controls, especially when these control costs are modest. Current estimates indicate that controls could be implemented for perhaps $1 \%$ to $2 \%$ of the capital costs associated with Ontario Hydro's nuclear recovery plans. Effective emission controls would establish a strong and credible foundation for the Canadian case in support of American emission reductions. Canadian credibility with American decision-makers in this area will be strong as long as there is steady, proactive progress in controlling Canadian emissions. A record of backsliding or inaction in Ontario will not only destroy that credibility, but could provide additional support for some industries and governments south of the border that are resisting the implementation of emission control standards.

Recommendations concerning restructuring of the electricity generation sector: The electricity generation sector is being restructured in both Canada and the United States. Legislation will be considered by the Ontario government, the American Congress and probably other governments in the near future.

- In general, electricity sector restructuring legislation in both countries must include more stringent sulphur dioxide and nitrogen oxides emission limits, applicable to all market participants.

- The most effective method for reducing all fossil fuel-related emissions is to use fossil fuel more efficiently, and to use alternative sources of fuel. Consequently, the OMA recommends that electricity sector restructuring legislation in Ontario must include a mechanism such as a 'system benefits charge', to create a fund dedicated to investment in cost effective energy efficiency and energy conservation projects. The fund, which would be similar to those already in existence in California, Maine, Massachusetts, New York and other jurisdictions, must be a non-bypassable component of the distribution 
service and collected on the basis of usage. A minimum of $\$ 100$ million per year should be collected and disbursed. The fund and disbursement decisions should be managed by an independent multistakeholder organization.

- Electricity sector restructuring legislation in Ontario must also include disclosure provisions whereby all existing and new electricity generation sources must provide regular, public reports showing emissions data for selected pollutants, especially sulphur dioxide and nitrogen oxides.

Recommendations concerning the control of sulphur dioxide:

- Ontario's emissions of sulphur dioxide should be reduced from current cap levels by $75 \%$, as recommended by the Acidifying Emissions Task Group.

- Similar reductions of sulphur dioxide should be required from sources in the United States beyond current requirements under the acid rain program contained in the American Clean Air Act. More immediately, there should be no exemptions under the Clean Air Act for old power plants that pollute at many times the rate of new power plants under current Clean Air Act standards. The principle of environmental comparability should be applied to all power plants competing in North America.

Recommendations concerning the control of nitrogen oxides:

- In the United States, controls on emissions of nitrogen oxides from the electric power sector should be no less stringent than 0.15 pounds/million BTU, and that this standard should be applied to all plants, with no exemptions for old plants.

- In Ontario, the government should replace Ontario Hydro's voluntary commitment to nitrogen oxides reductions with a regulation under the Environmental Protection Act that would limit the corporation's nitrogen oxides emissions (including emissions associated with any power imports from the United States) to no more than 6000 tonnes annually.

- In both Canada and the United States, if the trading of emission credits is allowed, a minimum of $10 \%$ of each state's or province's tonnage budget should be allocated solely to qualifying, verifiable, new end-use energy efficiency and renewable energy projects.

Recommendations concerning controlling emissions from the transportation sector: The transportation sector is a major producer of both nitrogen oxides and other ozone precursors, as well as fine particles. Part of the approach in dealing with the transportation sector involves engine and fuel modifications. Part of the approach involves appropriate and effective vehicle emission inspection and maintenance (I/M) programs.

- For major Canadian population areas such as the Windsor-Quebec corridor and other urban areas, light and heavy duty emission standards similar to those in force in the State of California should be adopted.

- Canadian jurisdictions should adopt and/or improve emission standards for light trucks, sport vehicles, off-road engines and diesel engines.

- The Ontario MOE, together with the Ministry of Transportation and the City of Toronto, should develop and implement a comprehensive plan for public transit in the Greater Toronto Area. The OMA recognizes that such an undertaking is very challenging, and it is not clear that the political and near term resources are present to accomplish such a task. Yet, without such a plan, the OMA is not confident that sufficient long term emission reductions can be achieved from the transportation sector in this heavily effected area.

- The MOE's new I/M program should be expanded to include public transit vehicles (buses and shuttle vans), commercial/transportation trucks, and taxi cabs/commercial limousines.

- American standards for vehicle gasoline vapour recovery systems, fuel reformulation gasoline dispensing stations and heavy-duty engines should be adopted.

- Ontario should adopt the California standard of 30 ppm sulphur-in-gasoline content. Regarding diesel fuel, a standard of 400 ppm off-road sulphur level should be adopted.

This scenario has been evaluated by a joint government/industry panel in a recent report (18), and the benefits far outweigh the economic costs associated with it. At a minimum, the sulphur-in-gasoline and diesel standards should be mandatory in the WindsorQuebec corridor, and are advisable for other areas of Ontario. A government working group is expected to make recommendations concerning this issue later in 1998.

Using Section 115 of the United States Clean Air Act: Depending on the outcome of current rule makings underway at the USEPA, transboundary flows of air pollution from the United States into Canada may continue to cause negative health and environmental effects. There is another remedy available to Canadians that should be considered. Section 115 of the American Clean Air Act allows for a petition by a foreign country (with Canada clearly in mind) to the USEPA administrator for relief from American pollution that is affecting that country. Action under Section 115 may be taken once a duly constituted international authority has determined that such damage is occurring, and requires that Canada have reciprocal legislation permitting a similar American intervention. Recent reports by, among others, the Commission for Environmental Co-operation established under the 
North American Free Trade Agreement have concluded that American air pollution is damaging Canada. Reciprocity has been in place in Canadian legislation since the 1980s.

- The Canadian government, the Ontario government or an appropriate municipal government should petition the USEPA Administrator to use Section 115 of the American Clean Air Act to require sulphur dioxide and nitrogen oxides emission reductions in the United States.

Additional recommendations concerning physician activities:

- Physicians should advocate the development of air pollution-related health education material for patients, teaching faculties and practising physicians.

The OMA should assist individual physicians in developing prescriptive advice for patients about health risks associated with air pollution exposure and environmental messages to advise the public on actions to take to reduce the emission of pollutants. It is recommended that health message content include an emphasis on 'diagnostic' versus 'prescriptive' messages (those that identify expected health effects versus those that recommend protective actions); identification of target groups; accurate reflection of the scientific evidence without unduly raising public concern; and selection of an appropriate threshold for the ground-level ozone advisory. Prescriptive advice should be obtained from local public health authorities and personal health care providers familiar with an individual's clinical history (16).

The OMA should form partnerships for education and health promotion. Working with stakeholders, such as the Registered Nurses Association of Ontario, Public Health Units, the Lung Association, Ontario College of Family Physicians and Pollution Probe, will help to ensure that the public is informed of air pollution's health effects.

Continued cooperative participation is required for the Physician Education Project in Workplace Health, an initiative begun in 1995 by the OMA Section on Occupational and Environmental Medicine, supported by the OMA and operating under the aegis of Educating Future Physicians of Ontario (EFPO). EFPO is supported by the five faculties of medicine of Ontario, the Ministry of Health and a consortium of associated medical services. Its goal is to make medical education more responsive to the evolving needs of Ontario society.

- Stakeholders including organized medicine should support research about the origins, characteristics and health impact of air pollutants.

Research is needed to define how fine particles affect cardiorespiratory disease, and how important air toxins (known or suspected to cause cancer or developmental abnormalities) are to overall cancer risk. Inhalable particulates, especially their sulphate compo- nent, had the greatest impact on air pollution premature mortality and hospital admissions in the Hamilton area study (6). Improved access to data associated with health effects of these pollutants is required (particularly emergency room visits and visits to physicians' offices or walk-in clinics).

Physicians should support improved communication and coordination among the various government initiatives at all levels, and in particular an increased prominence of the health agenda relative to these pollutants. For example, better coordination of activities of the various committees, task forces and other government groups dealing with sulphate particles is needed to organize and rationalize the various initiatives (especially at the federal level). Also, the OMA should insist that health issues be built into the activities of air quality initiatives. Personnel should be assigned to provide health advice to the Ministry of Environment.

- Physicians should advocate the development of uniform or standardized terminology.

On the health effects of the particulate matter, for example, a forum of eminent scientists might be drawn together to establish uniform terms and definitions so that future research does not suffer from inexactness. This expert panel could be composed of members from the Royal Society of Canada and the United States National Academy of Sciences.

- Individual physicians should be aware of smog advisories.

Physicians have been identified as important players in raising public awareness, the communication of risk, and the communication and promotion of strategies to avoid harmful exposure, and to change behaviour to reduce smog levels $(16,76)$.

In Ontario, the MOE reports daily on the air quality index (AQI), which is an aggregate of the six most common urban air pollutants: carbon monoxide, nitrogen dioxide, sulphur dioxide, suspended particles, total reduced sulphur and ozone. Since 1993, smog advisories have been issued when ozone levels are forecast to be significantly elevated (average regional levels greater than $80 \mathrm{ppb}$ ). About five such episodes are likely to occur over a summer. These smog advisories (much like the ultraviolet [UV] index) are reported by the media with health and environmental messages (10). Table 4 shows the health impacts of the AQI pollutants at various levels (3).

- It is recommended that implementation strategies, such as education programs, be directed towards individuals at risk, as well as parents, teachers, athletes, coaches, health professionals and public health officials (16).

- Physicians should be aware of the smog advisory and knowledgeable about the effects of smog. The following are suggested as important points to make to patients. 
TABLE 4

Air quality index pollutants and their impact

\begin{tabular}{|c|c|c|c|c|c|c|c|c|}
\hline Index & Category & $\begin{array}{l}\text { Carbon } \\
\text { monoxide }\end{array}$ & $\begin{array}{l}\text { Nitrogen } \\
\text { dioxide }\end{array}$ & Ozone & $\begin{array}{l}\text { Sulphur } \\
\text { dioxide }\end{array}$ & $\begin{array}{l}\text { Suspended } \\
\text { particles }\end{array}$ & $\begin{array}{l}\text { Sulphur } \\
\text { dioxide and } \\
\text { suspended } \\
\text { particles* }\end{array}$ & $\begin{array}{l}\text { Total reduced } \\
\text { sulphur (TRS) }\end{array}$ \\
\hline 0 to 15 & Very good & $\begin{array}{l}\text { No known } \\
\text { harmful } \\
\text { effects }\end{array}$ & $\begin{array}{l}\text { No known } \\
\text { harmful } \\
\text { effects }\end{array}$ & $\begin{array}{l}\text { No known harmful } \\
\text { effects }\end{array}$ & $\begin{array}{l}\text { No known } \\
\text { harmful effects }\end{array}$ & $\begin{array}{l}\text { No known } \\
\text { harmful } \\
\text { effects }\end{array}$ & $\begin{array}{l}\text { No known } \\
\text { harmful } \\
\text { effects }\end{array}$ & $\begin{array}{l}\text { No known } \\
\text { harmful } \\
\text { effects }\end{array}$ \\
\hline 16 to 31 & Good & $\begin{array}{l}\text { No known } \\
\text { harmful } \\
\text { effects }\end{array}$ & Slight odour & $\begin{array}{l}\text { No known harmful } \\
\text { effects }\end{array}$ & $\begin{array}{l}\text { Damages some } \\
\text { vegetation in } \\
\text { combination } \\
\text { with ozone }\end{array}$ & $\begin{array}{c}\text { No known } \\
\text { harmful } \\
\text { effects }\end{array}$ & $\begin{array}{l}\text { No known } \\
\text { harmful } \\
\text { effects }\end{array}$ & Slight odour \\
\hline 32 to 49 & Moderate & $\begin{array}{l}\text { Blood } \\
\text { chemistry } \\
\text { changes but } \\
\text { no noticeable } \\
\text { impairment }\end{array}$ & Odour & $\begin{array}{l}\text { Respiratory } \\
\text { irritation in } \\
\text { sensitive people } \\
\text { during vigorous } \\
\text { exercise; people } \\
\text { with heart/lung } \\
\text { disorders at } \\
\text { some risk; } \\
\text { damages very } \\
\text { sensitive plants }\end{array}$ & $\begin{array}{l}\text { Damages some } \\
\text { vegetation }\end{array}$ & $\begin{array}{l}\text { Some } \\
\text { decrease in } \\
\text { visibility }\end{array}$ & $\begin{array}{l}\text { Damages } \\
\text { vegetation } \\
\text { (ie, } \\
\text { tomatoes, } \\
\text { white beans } \\
\text { due to } \\
\text { sulphur } \\
\text { dioxide) }\end{array}$ & Odour \\
\hline 50 to 99 & Poor & $\begin{array}{l}\text { Increased } \\
\text { symptoms in } \\
\text { smokers with } \\
\text { heart disease }\end{array}$ & $\begin{array}{l}\text { Air smells and } \\
\text { look brown. } \\
\text { Some } \\
\text { increase in } \\
\text { bronchial } \\
\text { reactivity in } \\
\text { asthmatics }\end{array}$ & $\begin{array}{l}\text { Sensitive people } \\
\text { may experience } \\
\text { irritation when } \\
\text { breathing and } \\
\text { possible lung } \\
\text { damage when } \\
\text { physically } \\
\text { active; people } \\
\text { with heart/lung } \\
\text { disorders at } \\
\text { greater risk; } \\
\text { damage to } \\
\text { some plants }\end{array}$ & $\begin{array}{l}\text { Odorous; } \\
\text { increased } \\
\text { vegetation } \\
\text { damage }\end{array}$ & $\begin{array}{l}\text { Decreased } \\
\text { visibility; } \\
\text { soiling } \\
\text { evident }\end{array}$ & $\begin{array}{l}\text { Increased } \\
\text { symptoms } \\
\text { for people } \\
\text { with chronic } \\
\text { lung disease }\end{array}$ & Strong odour \\
\hline $\begin{array}{l}100 \text { and } \\
\text { over }\end{array}$ & Very poor & $\begin{array}{l}\text { Increased } \\
\text { symptoms in } \\
\text { nonsmokers } \\
\text { with heart } \\
\text { disease; } \\
\text { blurred vision; } \\
\text { some } \\
\text { clumsiness }\end{array}$ & $\begin{array}{l}\text { Increased } \\
\text { sensitivity in } \\
\text { asthmatics } \\
\text { and people } \\
\text { with } \\
\text { bronchitis }\end{array}$ & $\begin{array}{l}\text { Serious } \\
\text { respiratory } \\
\text { effects, even } \\
\text { during light } \\
\text { physical activity; } \\
\text { people with } \\
\text { heart/lung } \\
\text { disorders at high } \\
\text { risk; more } \\
\text { vegetation } \\
\text { damage }\end{array}$ & $\begin{array}{l}\text { Increased } \\
\text { sensitivity in } \\
\text { asthmatics and } \\
\text { people with } \\
\text { bronchitis }\end{array}$ & $\begin{array}{l}\text { Severe odour; } \\
\text { some } \\
\text { people may } \\
\text { experience } \\
\text { nausea and } \\
\text { headaches }\end{array}$ & $\begin{array}{l}\text { Significant } \\
\text { effects for } \\
\text { asthmatics } \\
\text { and people } \\
\text { with } \\
\text { bronchitis }\end{array}$ & $\begin{array}{l}\text { Severe odour; } \\
\text { some people } \\
\text { may } \\
\text { experience } \\
\text { nausea and } \\
\text { headaches }\end{array}$ \\
\hline
\end{tabular}

${ }^{*}$ As measured by the Air Pollution Index (API)

$\rightarrow$ There are health risks associated with smog exposure.

$\rightarrow$ During exposure to smog, you may experience eye irritation. Heavy outdoor exercise during the episode may cause respiratory symptoms. People with heart or lung disease (including asthma) may experience worsening of their condition. Outdoor activity should be reduced, and, if necessary, consult your physician (11).

$\rightarrow$ You should listen for the smog advisories and the UV Index.

$\rightarrow$ The probability and severity of effects increases with greater exposure, depending on ozone level, time spent outdoors and rate of breathing, which increases with exercise and is higher in children. $\rightarrow$ Symptoms that may be attributed to poor air quality include throat irritation, cough, shortness of breath and wheezing.

$\rightarrow$ When there is a smog advisory, you should avoid strenuous outdoor exercise, especially during the afternoon and early evening when ozone levels are highest. Choose indoor activities at these times.

$\rightarrow$ During a smog episode, it may be advisable to reschedule outdoor sport events, especially those for children, because outdoor exercise may pose a risk of exacerbating asthma in the $5 \%$ to $10 \%$ of children with asthma, and of causing respiratory symptoms in others. Morning events, when ozone levels are lower, are safer (10).

$\rightarrow$ Effective warnings should be issued to particularly 
susceptible individuals, such as those with asthma, to avoid exposure to air pollution (77).

\section{- Physicians should be informed about actions the public can take to reduce air pollutants and share this information with their patients.}

Environmental messages advise the public on actions to take to reduce the emission of pollutants, but the short term behaviour change will not produce immediate environmental improvement. It is not wise to walk or cycle, thereby increasing personal exposure, to help reduce smog during smog episodes. During a smog advisory, reduce car use by using transit or car pooling, and delay using other engines, such as lawn mowers, etc.

In the long term, primary prevention includes empowering patients to become part of the solution, by reducing emissions as follows.

$\rightarrow$ Reduce car use by using public transit, car pooling, walking or cycling.

$\rightarrow$ Buy a fuel-efficient vehicle, keep your car well tuned, check the emission control system and turn off your engine while waiting.

$\rightarrow$ Use alternatives to other gasoline-powered vehicles and machines, such as motorbikes, motorboats and gas lawn mowers.

$\rightarrow$ At home, think about reducing pollution emissions by considering energy efficiency.

Patients should be encouraged to learn more, join a group, speak out and take action in their community. This is especially important because the solution involves personal changes with respect to auto and energy use, societal changes with respect to transportation and urban planning, and federal action to reduce the transboundary transport of pollution from the United States (10).

\section{CONCLUSIONS}

There can be little doubt that ground-level ozone, particulates and acid aerosols are linked to increases in hospitalization for respiratory and cardiac disease, and to increased premature mortality. Socioeconomic effects include an unfair burden on children, and it is estimated that approximately 1400 hospital admissions per year in all of Ontario are due to the effects of inhalable particulates alone. Most important, there does not appear to be a threshold level for ground-level ozone or particulates below which no effects are observed; even low levels of ground-level ozone and particulates are damaging to the cardiorespiratory system (2).

It is clear that air pollution and health effects are of great concern to Ontarians. Not only are people concerned about air pollution, but investigations show people are prepared to pay for improvements to air quality as well (6).

The research that was reviewed by the OMA shows a number of gaps in knowledge and areas for further research (particularly concerning asthma). More details about the health and environmental effects of the pollutants, the sources of pollutants and projections of future trends in emissions are needed to create an effective strategy to improve air quality in Ontario (6).

Public policy should be based upon the best available evidence to give priority to strategies that are clearly effective. The public deserves a role in the process of determining rational risk choices. It is the public that bears the burden of illness and injury, as well as the economic impacts of air pollution. The people of Ontario must have meaningful representation of their views, no matter how much of a challenge this process may be to implement.

Actions must be taken on the findings and recommendations in this paper. Ground-level ozone, acid aerosols and particulate matter pose a serious health risk to the people of Ontario. An integrated and comprehensive approach by many stakeholders, including the active involvement of organized medicine, is required to address this important issue. While cognizant of the barriers to implementation of these recommendations, the OMA believes that the end benefits far outweigh the obstacles. The result will be a healthier society, and in particular, healthier children. The challenge that we face is to determine the best method to reduce these environmental emissions in a manner that is accepted and understood by industry and government. There are a great number of groups in the community who have an intense interest in and responsibility for this health problem, including health care providers, educators, parents, environmental agencies and groups, and legislators. The OMA urges every community to address the issue of health effects of ground-level ozone, acid aerosols and particulate matter in an aggressive and timely fashion.

ACKNOWLEDGEMENTS: The development of this postion paper was supported by the Helen McCrea Peacock Foundation. The Ontario Medical Association (OMA) expresses its gratitude to many individuals and representatives of groups for their contributions and valued comments during the development of this position paper, notably Michael Perley, former Executive Coordinator, Canadian Coalition on Acid Rain; Patricia North LLB, Project Officer of the OMA Health Policy Department; OMA Committee on Population Health; OMA Clincial Sections; and other outside reviewers such as environmental groups and agencies, clinicians, academics, and international experts and researchers.

\section{REFERENCES}

1. Ministry of Environment and Energy. Air quality in Ontario 1994 comprehensive report. Toronto: Queen's Printer for Ontario, 1995.

2. Great Lakes Health Effects Program - GLHEP. Outdoor Air and Your Health: A Summary of Research Related to the Health Effects of Outdoor Air Pollution in the Great Lakes Basin. Ottawa: Air Quality Health Effects Research Section, Environmental Health Directorate, Health Canada, 1996.

3. Ministry of Environment and Energy, Ontario. Air Quality in Ontario 1995. Toronto: Queen's Printer for Ontario, 1997.

4. Institute for Environmental Studies - University of Toronto in partnership with Pollution Probe. Emissions from Coal-fired Electric Utilities: Environmental Health Effects and Reduction Options. Toronto: Institute for Environmental Studies - University of Toronto in partnership with Pollution Probe, 1998.

5. American Thoracic Society, Committee of the Environmental and Occupational Health Assembly. Health effects of outdoor air pollution. Am J Respir Crit Care Med 1996;153:3-50.

6. Regional Municipality of Hamilton-Wentworth - sRMHW 
Hamilton-Wentworth Air Quality Initiative Summary Report. Hamilton: Regional Municipality of Hamilton, 1997.

7. Health and Welfare Canada. A New Perspective on the Health of Canadians. Ottawa: Government of Canada, 1974.

8. Shah CP. Public Health and Preventive Medicine in Canada, 3rd edn. Toronto: University of Toronto Press, 1994.

9. City of Toronto Committee on the Status of Women, The Older Women's Network, and Women Plan Toronto. Make Women's Needs Heard November 10, 1997: Information About Issues That May Impact Women in the 1997 Municipal Election. Toronto, 1997.

10. Abelsohn A. Pamphlet for Primary Care Physicians: Smog and Human Health. Toronto: Ontario College of Family Physicians, 1996.

11. The Lung Association - Hamilton-Wentworth and The Hamilton-Wentworth Air Quality Initiative. Fact Sheet \#4: Sources 199608 31. Hamilton: The Lung Association - Hamilton-Wentworth and The Hamilton-Wentworth Air Quality Initiative, 1996.

12. Middlesex-London Health Unit. State of the Environment: Air Quality. London: Middlesex-London Health Unit, 1997.

13. Ministry of Environment and Energy. Air Quality in Ontario, 1992. Toronto: Queen's Printer, 1993.

14. Hough AM, Derwent RG. Changes in the global concentration of tropospheric ozone due to human activities. Nature 1990;344:645-8.

15. The Acidifying Emissions Task Group. Towards a National Acid Rain Strategy. Ottawa: Environment Canada, 1997.

16. Stieb DM, Pengelly LD, Arron N, Taylor SM, Raizenne ME. Health effects of air pollution in Canada: Expert panel findings for the Canadian Smog Advisory Program. Can Respir J 1995;2:155-160.

17. Joint Industry/Government Study. Sulphur in Gasoline and Diesel Fuels: Atmospheric Science Expert Panel Report. Ottawa: Enquiry Centre, Environment Canada, 1997.

18. Joint Industry/Government Study. Sulphur in Gasoline and Diesel Fuels: Health and Environmental Impact Assessment Panel Report. Ottawa: Enquiry Centre, Environment Canada, 1997.

19. Pope CA. Particulate pollution and health: A review of the Utah Valley experience. J Expo Anal Environ Epidemiol 1996;6:23-34.

20. American Thoracic Society. Guidelines as to what constitutes an adverse respiratory health effect, with special reference to epidemiologic studies of air pollution. Am Rev Respir Dis 1985;131:666-8.

21. Bates DV. Health indices of adverse effects of air pollution. The question of coherence. Environ Res 1992;59:336-49.

22. Albright JF, Goldstein RA. Airborne pollutants and the immune system. Otolaryngol Head Neck Surg 1996;114:232-8.

23. Utell MJ, Samet JM. Air pollution in the outdoor environment. In: Brooks SM, Gochfeld M, Herzstein J, Jackson RJ, Schenker MB, eds. Environmental Medicine. St Louis: Mosby YearBook Inc, 1995.

24. McDonnell WF, Horstman S, Abdul-Salaam S, House DE. Reproducibility of individual responses to ozone exposure. Am Rev Respir Dis 1985;131:36-40.

25. Brauer M, Blair J, Vedal S. Effect of ambient ozone exposure on lung function in farm workers. Am J Respir Crit Care Med 1996;154:981-7.

26. World Health Organization Regional Office for Europe. Air Quality Guidelines for Europe. Copenhagen and Geneva: WHO/EURO, 1987.

27. Environmental Protection Agency. Air Quality Criteria for Oxides of Nitrogen. Washington DC: Environomental Protection Agency, 1993.

28. Lebowitz MD. Epidemiological studies of the respiratory effects of air pollution. Eur Respir J 1996;9:1029-54

29. Bates DV. Observations on asthma. Environ Health Perspect 1995;103(Suppl 6):243-7.

30. Mao Y, Semenciw R, Morrison H, MacWilliam L, Davies J, Wigle D. Increased rates of illness and death from asthma in Canada. Can Med Assoc J 1987;137:620-4

31. Thurston GD, Lippmann M, Scott MB, Fine JM. Summertime haze air pollution and children with asthma. Am J Respir Crit Care Med 1997; 155:654-60.

32. Peden DB, Setzer RW Jr, Devlin RB. Ozone exposure has both a priming effect on allergen induced responses and an intrinsic inflammatory action in the nasal airways of perennially allergy asthmatics. Am J Respir Crit Care Med 1995;151:1336-45.

33. Gordon T, Fine J. The contribution of ambient air pollution to allergic asthma. Toxicol Ecotoxicol Newslet 1997;4:20-4.

34. Molfino NA, Wright SC, Katz I, et al. Effect of low concentrations of ozone on inhaled allergen responses in asthmatic subjects. Lancet 1991;338:199-203

35. Ackermann-Liebrich U, Leuenberger P, Schwartz J, et al. Lung function and long term exposure to air pollutants in Switzerland. Am J Respir Crit Care Med 1997;155:122-9.

36. Dockery DW, Pope CA, Xu X, et al. An association between air pollution and mortality in six U.S. cities. N Engl J Med 1993;329:1753-9.

37. Schwartz J. Air pollution and daily mortality: A review and meta analysis. Environ Res 1994;64:36-52.

38. Thurston GD, Ito K, Hayes CG, Bates DV, Lippmann M. Respiratory hospital admissions and summertime haze air pollution in Toronto: Consideration of the role of acid aerosols. Environ Res 1994;65:271-90.

39. Schwartz J, Dockery DW, Neas LM. Is daily mortality associated specifically with fine particles? J Air Wast Manage Assoc 1996;46:927-99.

40. Ozkaynak A, et al. Association between daily mortality and air pollution in Toronto, Canada. Proceedings of the International Society for Environmental Epidemiology. Noordwijkerhourt, The Netherlands. August 1995

41. Ministry of Environment and Energy. Towards a smog plan for Ontario: A discussion paper. Toronto: Ministry of Environment and Energy, June 1996.

42. Inhalable Particulates and Respirable Particulates (IP/RP) Strategy Working Group, D Pengelly, chair. Bulletin on inhalable and respirable particulates (IP\&RP), IP/RP Progress Note \#1, prepared for Ontario Smog Plan. November, 1996.

43. Katsouyanni K, Touloumi G, Spix C, et al. Short-term effects of ambient sulphur dioxide and particulate matter on mortality in 12 European cities: results from time series data from the APHEA project. Air Pollution and Health: a European Approach. BMJ 1997;314:1658-63.

44. Bates DV. Environmental Health Risks and Public Policy. Seattle: University of Washington Press, 1994:117.

45. Gamble JF, Lewis RJ. Health and respirable particulate $\left(\mathrm{PM}_{10}\right)$ air pollution: A causal or statistical association? Environ Health Perspect 1996;104:838-50.

47. Schwartz J, Spix C, Touloumi G, et al. Methodological issues in studies of air pollution and daily counts of deaths or hospital admissions. J Epidemiol Commun Health 1996;50(Suppl 1):S3-11.

48. Delfino R, Becklake MR, Hanley JA. Reliability of hospital data for population-based studies of air pollution. Arch Environ Health 1993;48:140-6.

49. Oreskes N, Shrader-Frechette K, Belitz K. Verification, validation, and confirmation of numerical models in earth sciences. Science 1994;263:641-6.

50. Barr BC, Hyde DM, Plopper CG, Dungworth DL. Distal airway remodeling in rats chronically exposed to ozone. Am Rev Respir Dis 1988;137:924-38.

51. Kinney PL, Thurston GD, Raizenne M. The effects of ambient ozone on lung function in children: A reanalysis of six summer camp studies. Environ Health Perspect 1996;104:170-4.

52. Korc ME. A socioeconomic assessment of human exposure to ozone in the South Coast Air Basin of California. J Air Wast Manage Assoc 1996;46:547-57.

53. Pengelly LD. Correspondence to OMA Health Policy Department. February, 1998.

54. Ransom MR, Pope CA III. Elementary school absences and PM10 pollution in Utah Valley. Environ Res 1992;58:204-9.

55. Dockery DW, Cunningham J, Damokosh AI, et al. Health effects of acid aerosols on North American children: Respiratory symptoms. Environ Health Perspect 1996;104:500-5.

56. Raizenne M, Neas LM, Damokosh AI, et al. Health effects of acid aerosols on North American children: Pulmonary function. Environ Health Perspect 1996;104:506-4.

57. Bates DV. The effects of air pollution on children. Environ Health Perspect 1995;103(Suppl 6):49-53.

58. Marwick C. New focus on children's environmental health. JAMA 1997;277:871-2.

59. Statistics Canada. Population ageing and the elderly [cat no 91-533E]. Ottawa: Statistics Canada, 1993.

60. Rosenberg MW, Moore EG. The health of Canada's elderly population: current status and future implications. Can Med Assoc J 1997; 157:1025-32.

61. Delfino RJ, Murphy-Mouton AM, Burnett RT, Brook JR, Becklake MR. Effects of air pollution on emergency room visits for respiratory illnesses in Montreal, Quebec. Am J Respir Crit Care Med 1997; $155: 568-76$ 
62. Bates DV, Sizto R. Relationship between air pollutants and hospital admissions in southern Ontario. Can J Public Health 1983;74:117-22.

63. Bates DV, Sizto R. Hospital admissions and air pollutants in southern Ontario: the acid summer haze effect. Environ Res 1987;43:317-31.

64. Bates DV. The Strength of the Evidence Relating Air Pollutants to Adverse Health Effects. Carolina Environmental Essay Series. Chapel Hill: Institute for Environmental Studies, University of North Carolina, 1985.

65. Keeler GJ, Spengler JD, Koutrakis P, Allen GA, Raizenne M, Stern B1. Transported acid aerosols measured in southern Ontario. Atmospher Environ 1990;24A:2935-50.

66. Plagiannakos T, Parker J. An assessment of air pollution effects on human health in Ontario Energy Economics Section, Economic and Forecasters Division, Ontario Hydro, File No 706.01 (\#260) March 1988.

67. Bates DV. Ozone: A review of recent experimental, clinical and epidemiological evidence, with notes on causation. Part 2. Can Respir J 1995;2:161-71.

68. Burnett RT, Dales RE, Raizenne ME, et al. Effects of low ambient levels of ozone and sulfates on frequency of respiratory admissions to Ontario hospitals. Environ Res 1994;65:172-94.

69. Stieb D, Burnett RT, Beveridge RC, Brook JR. Association between ozone and asthma emergency department visits in Saint John New Brunswick, Canada. Environ Health Perspect 1996;104:1354-60.

70. Stieb D, Beveridge RC, Brook JR, Burnett RT, Anis AH, Dales RE.
The Saint John Particle Health Effects Study. Measuring health effects, health costs and quality of life impacts using enhanced administrative data: Design and preliminary results. In: Particulate Matter: Health and Regulatory Issues, Proceedings of an International Speciality Conference, Pittsburgh, Pennsylvania, April 4-6, 1995. Pittsburgh: Air and Waste Management Association, 1995:131-42.

71. Burnett RT, Brook JR, Yung WT, Dales RE, Krewski D. Association between ozone and hospitalization for respiratory diseases in 16 Canadian cities. Environ Res 1997;72:24-31.

72. Thurston GD, Gorczynski JE Jr, Currie J, et al. The nature and origins of acid summer haze air pollution in metropolitan Toronto, Ontario. Environ Res 1994;65:254-70.

73. Bates DV. Adverse health impacts of air pollution - continuing problems. Scand J Work Environ Health 1995:21:405-11.

74. Guest CS, Morgan P, Moss JF, Woodward AJ, McMichael AJ. Abatement of tropospheric ozone: effects of strategies to improve air quality on public health and other sectors. Aust NZ J Public Health 1996;20:301-8.

75. McAndrew B. "Ministry won't set limits on Hydro's air pollution”. The Toronto Star, January 12, 1998:A2.

76. Pengelly LD, Taylor SM, Stieb D. Canadian Smog Advisory. Health Matrices for Ozone and Suspended Particles. Final Report. Health and Welfare Canada. Ottawa: Environmental Health Directorate, 1993.

77. Thurston GD, Leber M. The relationship between asthma and air pollution. In: Brenner B, ed. Emergency Asthma. New York: Marcel-Dekker. (In press) 


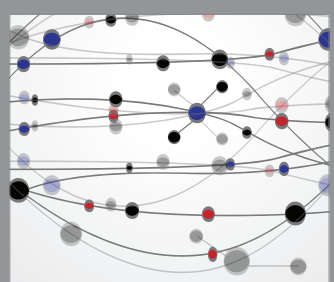

The Scientific World Journal
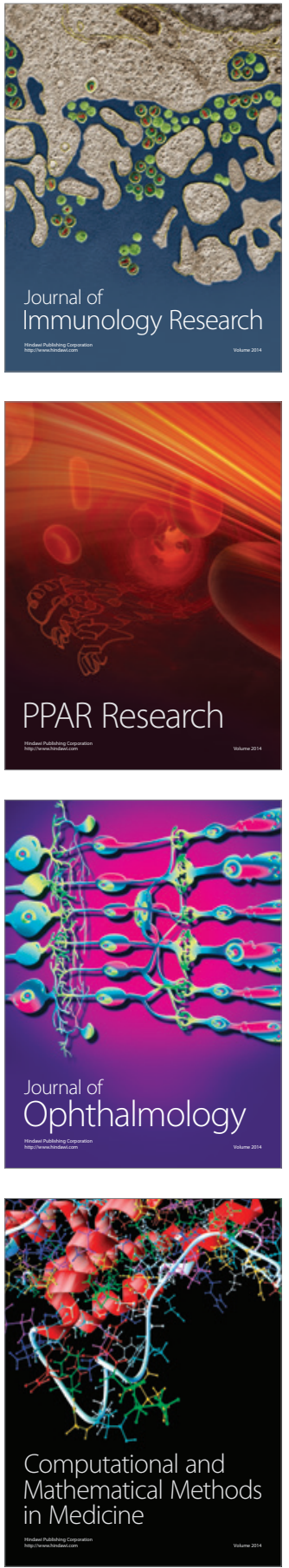

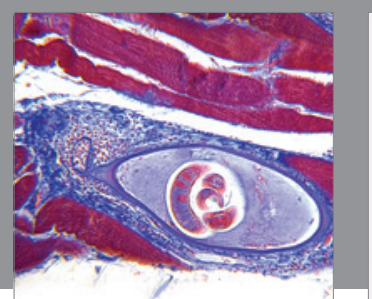

Gastroenterology Research and Practice

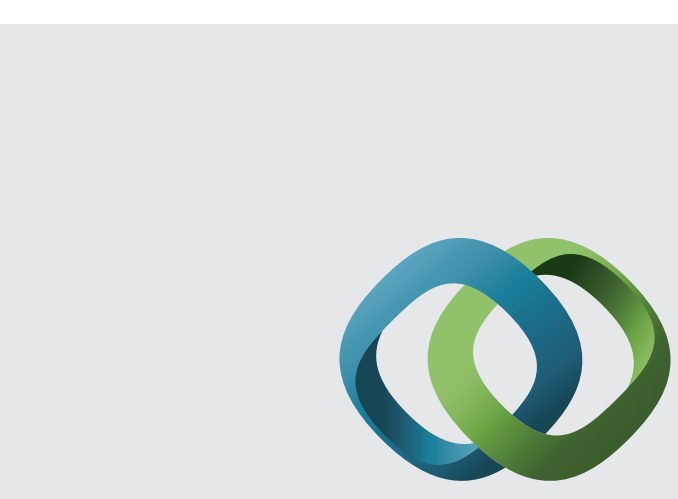

\section{Hindawi}

Submit your manuscripts at

http://www.hindawi.com
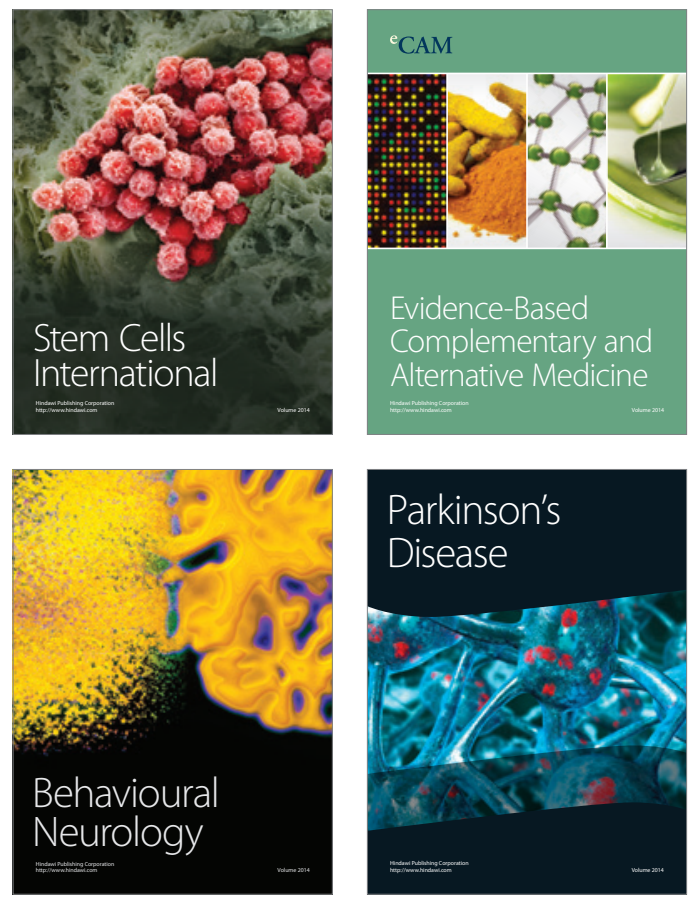
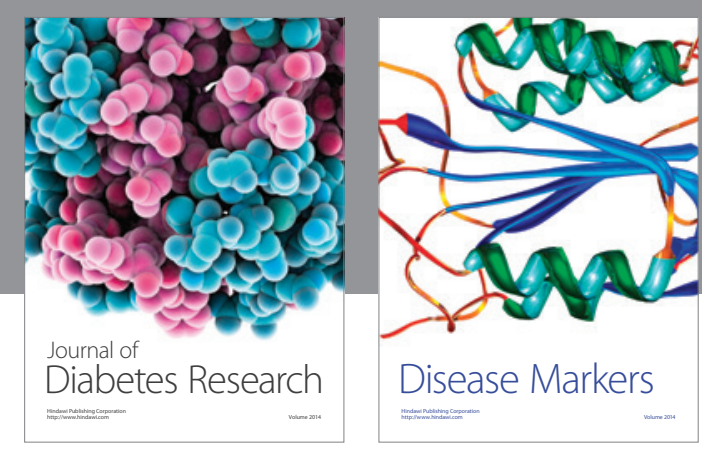

Disease Markers
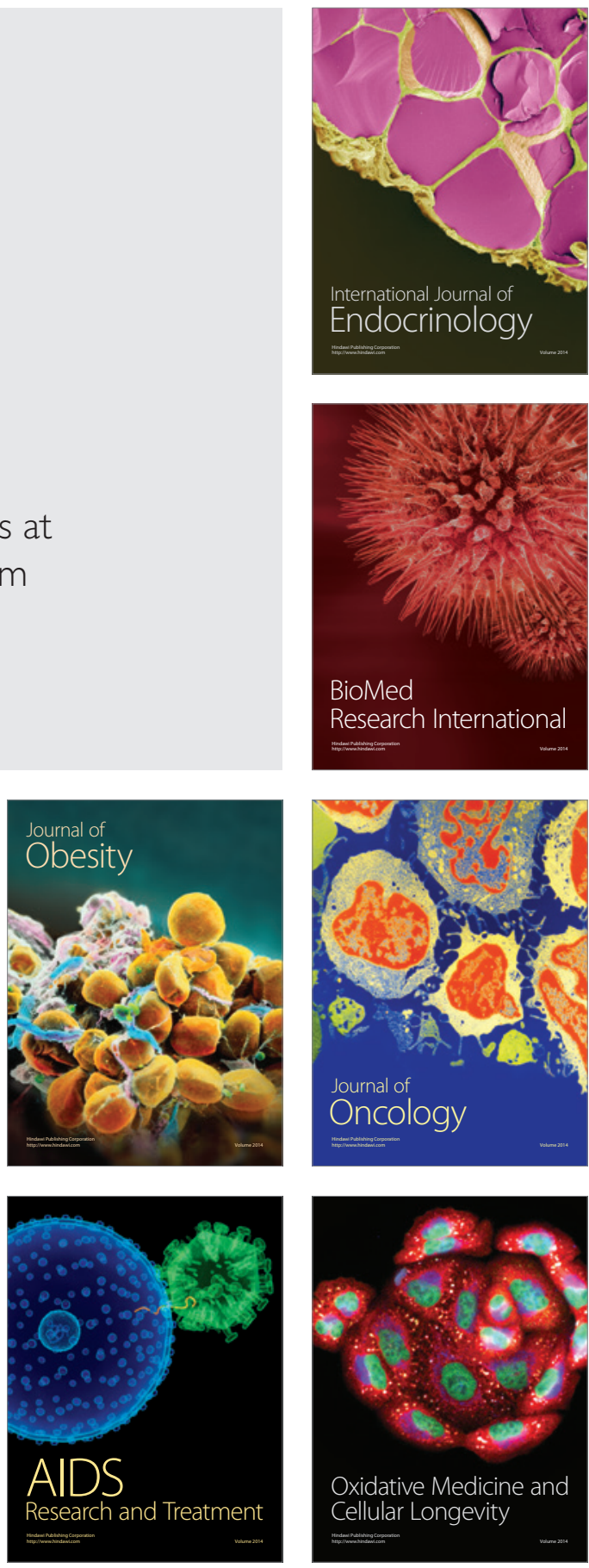